\title{
TU/e Emphoven

\section{A three dimensional two arch model of a normal foot for stress analysis}

Citation for published version (APA):

Shanti, J., Patil, K. M., Braak, L. H., \& Huson, A. (1995). A three dimensional two arch model of a normal foot for stress analysis. In S. K. Guha (Ed.), Proceedings of the 1st regional conference, IEEE Engineering in Medicine and Biology Society, and 14th conference of the Biomedical Engineering Society of India : an international meeting, February 15-18, 1995, New Dehli Institute of Electrical and Electronics Engineers.

Document status and date:

Published: 01/01/1995

\section{Document Version:}

Publisher's PDF, also known as Version of Record (includes final page, issue and volume numbers)

\section{Please check the document version of this publication:}

- A submitted manuscript is the version of the article upon submission and before peer-review. There can be important differences between the submitted version and the official published version of record. People interested in the research are advised to contact the author for the final version of the publication, or visit the $\mathrm{DOI}$ to the publisher's website.

- The final author version and the galley proof are versions of the publication after peer review.

- The final published version features the final layout of the paper including the volume, issue and page numbers.

Link to publication

\section{General rights}

Copyright and moral rights for the publications made accessible in the public portal are retained by the authors and/or other copyright owners and it is a condition of accessing publications that users recognise and abide by the legal requirements associated with these rights.

- Users may download and print one copy of any publication from the public portal for the purpose of private study or research.

- You may not further distribute the material or use it for any profit-making activity or commercial gain

- You may freely distribute the URL identifying the publication in the public portal.

If the publication is distributed under the terms of Article 25fa of the Dutch Copyright Act, indicated by the "Taverne" license above, please follow below link for the End User Agreement:

www.tue.nl/taverne

Take down policy

If you believe that this document breaches copyright please contact us at:

openaccess@tue.nl

providing details and we will investigate your claim. 


\title{
A THREE DIMENSIONAL TWO ARCH MODEL OF A NORMAL FOOT FOR STRESS ANALYSIS
}

\author{
Shanti Jacob*, K.M. Patil, L.H. Braak', A. Huson ${ }^{++}$
}

* Department of Applied Mechanics, Indian Institute of Technology, Madras, India

Department of Fundamentals of Mechanical Engineering, Eindhoven University of Technology, Eindhoven, The Netherlands Department of Movement Sciences, Faculty of Health Sciences, University of Limburg, Maastricht, The Netherlands

\section{ABSTRACT}

A three dimensional two arch model of the foot skeleton with cartilages and aments between bone segments is developed taking into account the 7) ping mid-stance phase of walking for a normal foot. The stress analyses are iring mid-stance phase of wing finite element software package NISA. The results of these thilyses could possibly help in understanding better the factors contributing to tarsal disintegration in leprosy.

Keywords: 3-D Foot Model, stress analysis, normal foot

\section{INTRODUCTION}

Knowledge of stresses that occur throughout normal and abnormal feet under rious loading conditions is of fundamental importance in understanding the physiology and pathophysiology of the foot, and can provide important information for the prevention and treatment of diseases like leprosy or Jiabetes. Leprosy is still a widespread disease in India as well as in many other countries in the world. The weakness or paralysis of foot muscles as occurring in leprosy or diabetes is found to alter the pattern of internal stresses in the foot skeleton. This may provoke a local foci of relatively high stresses. In those cases where osteoporosis and cystic degeneration has weakened the mechanical strength of the bones, these relatively excessive stresses may lead eventually to a local break down of the bone. These internal stresses cannot be measured in ivo, but can be predicted using an apprupriate mathematical or numerical Thodel of the foot. It is necessary to model a normal foot before calculating the stresses in a diseased foot.

Available foot models that can be used for stress analysis are two imensional models [1,2]. In the first two dimensional model [1], the foot keleton is simplified as a single bone while considering the shape variation of The bones and forces due to muscies, triceps surae and tibialis anterior and ankle joint force are taken into account to find the possible regions of high stresses. In the second model [2], the earlier. foot model is modified by introducing cartilages and ligaments between the bones and the effect of these, on stress distribution, are studied.

Modelling of the foot confronts inherently a three dimensional problem, one to which results from two dimensional analyses cannot necessarily be directly extrapolated. The stresses developed in the foot depend upon the geometry of the foot, and magnitade and insertion points of the muscle forces. Hence it is recessary to model the foot in all the three dimensions of geometry to make a more realistic representation. Therefore, in this study, a three dimensional nodel of the normal foot skeleton with cartilages and ligaments which enable Simulation of articulations (joints) is developed in the mid-stance phase of Thalking and stress analyses are carried out using finite element technique. Estimation of the regions of high stresses in the normal feet could. help in understanding the factors contributing to disintegration of tarsal bones in teprosy or diabetic patients.

\section{METHODOLOGY}

The three dimensional geometry of the foot is obtained from medio-lateral and antero-posterior radiographic measurements of a normal foot and by measurements on a cadaver foot. One approximate method of treating dynamic loading during waiking is in a quasi-static fashion by adding inertia forces to the body weight. The present model is used to study the regions of high stresses, taking into account the inertia forces from literature. The finite element method became the logical choice for the analysis of the present model due to its unique capability to analyse structures of complex shape, loading and material behaviour where the focus is on the internal stress distribution. The analysis is carried out using NISA (Numerically Integrated Elements for System Analysis) softwàre.
Huiskes and Chao [3] have reported that in the case of quasi-static loading, both cortical and trabecular bones behave linear elastic by approximation. Under short term or instantaneous loading, some useful information can be gained by modelling the cartilage as a linear elastic material, reported by Clift [4]. In this study, the foot bone material and the cartilages are assumed to be homogeneous, isotropic [2] and linear elastic. Young's modulus of the bone is taken as $7300 \mathrm{~N} / \mathrm{mm}^{2}$ and Poisson's ratio 0.3 [5] and that of the cartilage is faken as $10 \mathrm{~N} / \mathrm{mm}^{2}$ and 0.4 [6] respectively. The stiffness of the ligaments is taken as $1500 \mathrm{~N} / \mathrm{mm}$ [2].

\section{FOOT MODEL}

In the present work, a three dimensional foot model, consisting of the two arches namely, medial arch and lateral arch, is developed to simulate the midstance phase. The medial arch consists of the bones talus, navicular, three cuneiforms, three metatarsals and three toes. The lateral arch consists of calcaneus, cuboid, two metatarsals and two toes. Only ons phalanx is modelled. In both medial arch and lateral arch, the bones in the medio-lateral directions are combined together. The cartilages between the bones are also modelled with their respective medial and lateral ligaments both on plantar and dorsal sides. The complex cartilage between calcaneus and talus is also introduced with medial and lateral ligaments and interosseous ligaments. Ligaments are provided connecting the medial arch and lateral arch in addition to the above ligaments. The predominant muscle forces are taken into consideration using anatomical data $[7,8]$ for the points of origin and insertion points.

The foot model is idealised as an assemblage of eight noded isoparametric solid brick elements representing the bones and cartilages and two noded rod elements representing the ligaments. The brick elements have three translational degrees of freedom per node. The meshes used are fine at areas of high stress gradients and the final mesh is decided based on a convergence study of the maximum deflection of the model.

In the mid-stance phase the foot is supported at the heel and the forefoot. The ankle joint load (FAN) is simulated by 3.5 times the body weight of a normal subject [9] weighing $600 \mathrm{~N}$. During the mid-stance phase the muscles triceps surae (TS), peroneus longus (PL), peroneus brevis (PB), tibialis posterior (TP), flexor hallucis longus (FHL) and flexor digitorum longus (FDL) act predominantly on the foot $[10,11]$ and the forces in these muscles are obtained from literature $[11,12]$. The forces on the calcaneis due to the muscles FHL, FDL and TP as they go around the medial pulley and PL and PB around the lateral pulley are also considered in this model. Fig. 1 shows the model acted upon by the muscle forces. The finite element model as shown in Fig. 2 has 1475 brick elements to represent the bones and cartilages and 77 rod elements to model the ligaments.

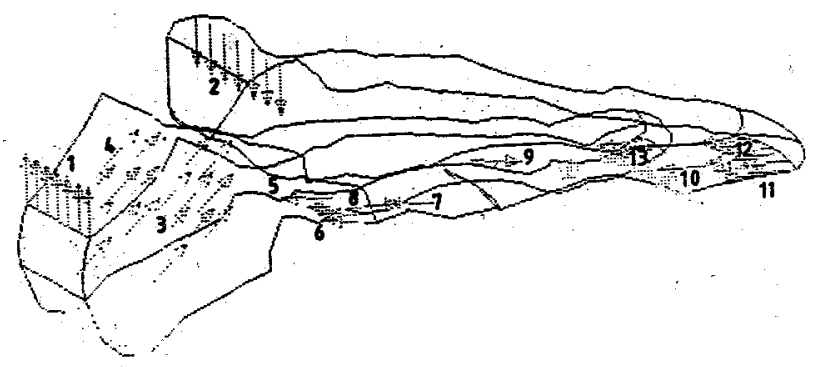

Fig. 1 Two arch model of the normal foot in mid-stance phase. The muscle forces acting . are indicated by numbers 1 through 12 .-1-Muscle force in triceps surae (1S), 2 - Ankex joint force (FAN), 3- Reaction on the medial pulley due to muscle forces lexor hallucis longus (FHL), flexor digitorm longus (FDL) and tibialis posterior (TP), 4- Reaction on the lateral pulley due to peroneus longus (PL) and peroneus brevis (PB), 5-Muscle force in PB, 6-Muscle force in TP, 7-Muscle force in PL, 8, 9\& 10- Muscle forces force in PB, 6-Muscle force in TP, 7-Muscle force in Pallucis (AH), 11-Muscle force in FHL and 12 \& 13 Muscle forces in FDL.

COPYRIGHT CLEATANCE CODE 0-7303-2711-X 


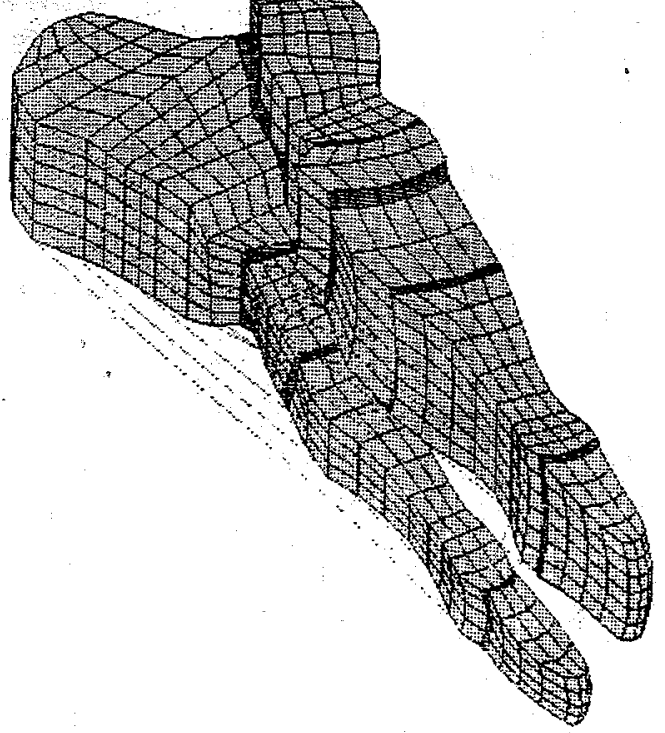

Fig. 2 Finite element discretization of the two arch model in mid-stance phase

\section{RESULTS}

Fig. 3 shows the von Mises stress contour of the two arch model. The stress The other high stressed regions are the jun $\left(8.1 \mathrm{~N} / \mathrm{mm}^{2}\right)$ near the ankle joint $\left.\mathrm{N} / \mathrm{mm}^{2}\right)$, medial pulley $\left(6.9 \mathrm{~N} / \mathrm{mm}^{2}\right)$, plantar side of calcaneus and cuboid $(7.5$ near the medial metatarsal head $\left(6.9 \mathrm{~N} / \mathrm{mm}^{2}\right)$, of the navicular $\left(6.9 \mathrm{~N} / \mathrm{mm}^{2}\right)$, $\left.\mathrm{N} / \mathrm{mm}^{2}\right)$, near the heel support $\left(4.6 \mathrm{~N} / \mathrm{mm}^{2}\right)$, plantar side of cuneiform $(5.8$ (4.6 N/mm $)$ near the junction of talus and and the dorsal side of the talus view of the foot model with von Mises stress contur. Fig. 4 shows a different predominantiy compressive in nature at these tour. The principal stresses are principal stresses in the cartilages are all compresions. It is found that the ismall magnitude

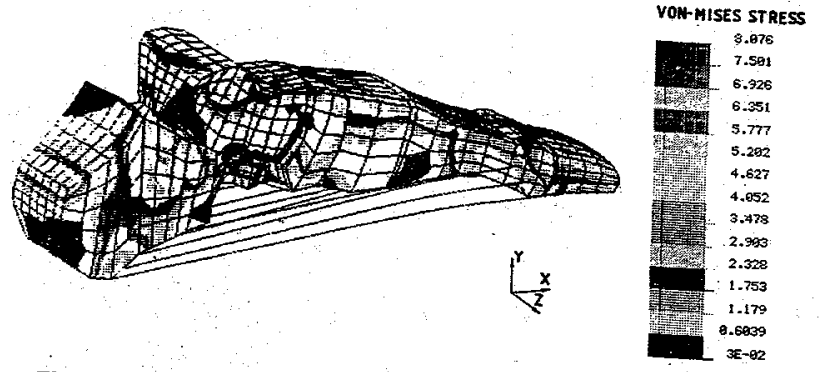

Fig. 3 Von Mises stress contour of the two arch model in mid-stance phase
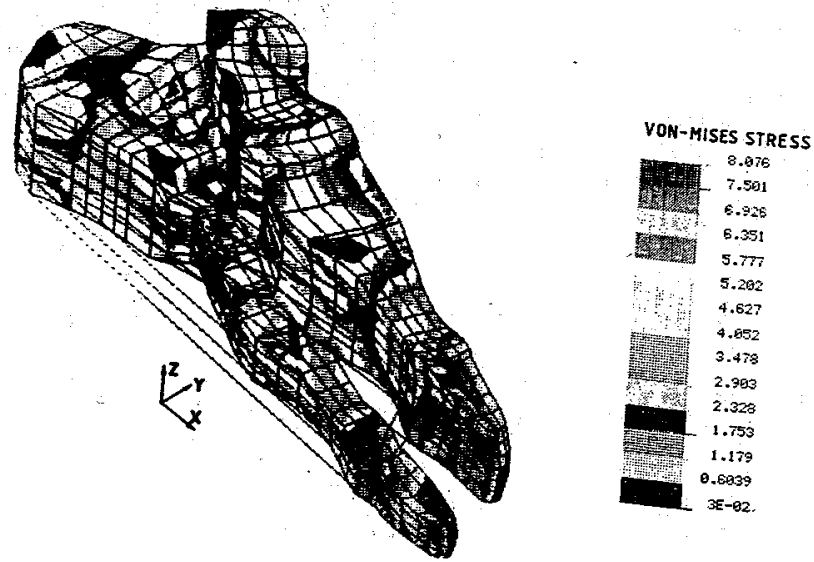

Fig. 4 A different view of the von Mises stress contour of the two arch model Proceedings RC IEEE-EMBS \& 14th BMESI - 1995
The high stress regions during the mid-stance phase are found near the ankle joint. The other areas of high stresses are the junction of calcaneus and cuboid medial pulley, plantar side of the navicular, near the medial metatarsal support plantar side of cuneiform, near the heel support and at the dorșal side of the talus near the junction of talus and navicular.

The two dimensional analysis [2] gives high von Mises stresses only/at the dorsal anterior face of the talus whereas in the present three dimensional study eight areas as indicated above are subjected to high stresses. This differences i results as compared to two dimensional case could be due to the introduction of the three dimensional geometry and the three dimensional location of the of the human foot. These areas of is found from the these areas of the clinical reports that in certain leprosy patients [13], some of decreased mechanis disintegrated if subjected to osteoporosis due to could possiblyanical strength of the bone in that region. This investigation disintegration in leprosy.

\section{ACKNOWLEDGEMENT}

The authors gratefully acknowledge the grant given by the Department of Science and Technology, New Delhi, Eindhoven University of Technology Euccess of this University of Limburg, Maastricht, The Netherlands, in the

\section{REFERENCES}

[1] Patil KM, Braak LH and Huson A (1993) "Stresses in a simplified two dimensional model of a normal foot - a preliminary analysis" Mechanics Research Communications, Vol 20, No 1, pp 1-7.

[2] Patil KM, Braak LH. and Huson A (1993) "A two dimensional model of a normal foot with cartilages and ligaments for stress analysis" Innov. Tech. Biol. Med. Vol 14, No 2, pp 152-162.

[3] Huiskes R and Chao EYS (1983) "A survey of finite element analysis in orthopedic biomechanics: the first decade" J. Biomechanics, Vol 16, No 6, pp
385-409.

[4] Clift SE (1992) "Finite-element analysis in cartilage biomechanics" J. Biomed. Eng., Vol 14, No 6, pp 217-221.

[5] Nakamura S, Crowninshield RD and Cooper RR (1981) "An Analysis of Soft Tissue Loading in the Foot -A Preliminary Report" Bull. Prosth. Res., Vol 18, No 1, pp 27-34.

[6] Schreppers GMMA; Sauren AAHJ and Huson A (1990) "A numerical model of the load transmission in the tibio-femoral contact area" Proceedings of the Institution of Mechanical Engineers, Vol 204, pp 53-59.

[7] McMinn RMH, Hutchings RT and Logan BM (1989) $A$ Colour Atlas of Foot and Ankle Anatomy, Wolfe Medical Publications Ltd., Brook House, London.

[8] Willians PL, Warwick R, Dyson M and Bannister LH (1989) Gray's Anatomy, 37th ed., Churchill \& Livingstone, New York.

[9] ROhrl H, Scholten R, Sigolotto C and Sollbach W (1984) "Joint forces in the human pelvis-leg skeleton during walking" J. Biomechanics, Vol 17, No 6, pp
409-424.

[10] Basmajian JV (1978) Muscles alive- their function revealed by electromyography, Williams \& Wilkins Co., Baltimore, pp 247-277.

[11] Seireg A and Arvikar RJ (1975) "The prediction of muscular load sharing and joint forces in the lower extremities during walking", J. Biomechanics, Vol 8 , No 1, pp 89-102.

[12] Calderale PM and Scelfo G (1987) "A mathematical model of the locomotor apparatus" Engineering in Medicine, Vol 16, pp 147-161

[13] Kulkarni VN, Mehta JM, Sane SB and Sharangpani RC (1985) "Study of tarsal disintegration in leprosy" Proc. Intl. Conf. on Biomech. \& Clini. Kinsiology of Hand \& Foot, Indian Institute of Technology, Madras, pp 121-124. 